\title{
Dark-induced senescence of barley leaves involves activation of plastid transglutaminases
}

\author{
E. Sobieszczuk-Nowicka • A. Zmienko • A. Samelak-Czajka • M. Luczak • \\ M. Pietrowska-Borek $\cdot$ R. Iorio $\cdot$ S. Del Duca $\cdot$ M. Figlerowicz $\cdot$ J. Legocka
}

Received: 1 August 2014 / Accepted: 27 December 2014 / Published online: 13 January 2015

(C) The Author(s) 2015. This article is published with open access at Springerlink.com

\begin{abstract}
Transglutaminases (E.C. 2.3.2.13) catalyze the post-translational modification of proteins by establishing $\varepsilon$ - $(\gamma$-glutamyl) lysine isopeptide bonds and by the covalent conjugation of polyamines to endo-glutamyl residues of proteins. In light of the confirmed role of transglutaminases in animal cell apoptosis and only limited information on the role of these enzymes in plant senescence, we decided
\end{abstract}

Handling Editor: S. Beninati.

Electronic supplementary material The online version of this article (doi:10.1007/s00726-014-1912-y) contains supplementary material, which is available to authorized users.

E. Sobieszczuk-Nowicka $(\bowtie) \cdot$ A. Samelak-Czajka $\cdot$ J. Legocka Department of Plant Physiology, Faculty of Biology, Adam Mickiewicz University of Poznań, ul. Umultowska 89,

61-614 Poznań, Poland

e-mail: evaanna@man.poznan.pl

A. Zmienko $\cdot$ M. Łuczak $\cdot$ M. Figlerowicz Institute of Bioorganic Chemistry, Polish Academy of Sciences, ul. Noskowskiego 12/14, 61-704 Poznań, Poland

\section{A. Zmienko $\cdot$ A. Samelak-Czajka $\cdot$ M. Figlerowicz Institute of Computing Science, Poznań University of Technology, ul. Piotrowo 2, 60-965 Poznan, Poland}

M. Pietrowska-Borek

Department of Plant Physiology, Poznań University of Life

Sciences, ul. Wołyńska 35, 60-637 Poznań, Poland

M. Pietrowska-Borek

Department of Biochemistry and Biotechnology, Poznań University of Life Sciences, ul. Wołyńska 35, 60-637 Poznań, Poland

R. Iorio · S. Del Duca

Department of Biological, Earth and Environmental Sciences,

University of Bologna, via Irnerio 42, 40126 Bologna, Italy

e-mail: stefano.delduca@unibo.it to investigate the activity of chloroplast transglutaminases (ChlTGases) and the fate of chloroplast-associated polyamines in Hordeum vulgare L. 'Nagrad' leaves, where the senescence process was induced by darkness (day 0) and continued until chloroplast degradation (day 12). Using an anti-TGase antibody, we detected on a subcellular level, the ChlTGases that were associated with destacked/degraded thylakoid membranes, and beginning on day 5 , were also found in the stroma. Colorimetric and radiometric assays revealed during senescence an increase in ChlTGases enzymatic activity. The MS/MS identification of plastid proteins conjugated with exogenous polyamines had shown that the ChlTGases are engaged in the post-translational modification of proteins involved in photosystem organization, stress response, and oxidation processes. We also computationally identified the cDNA of Hv-Pngl-like, a barley homologue of the Arabidopsis AtPngl gene. Its mRNA level was raised from days 3 to 10 , indicating that transcriptional regulation controls the activity of barley ChlTGases. Together, the presented results deepen our knowledge of the mechanisms of the events happened in dark-induced senescence of barley leaves that might be activation of plastid transglutaminases.

Keywords Chloroplast - Leaf · Hv-Pngl-like gene · Polyamines $\cdot$ Senescence $\cdot$ Transglutaminases

\begin{tabular}{|c|c|}
\hline \multicolumn{2}{|c|}{ Abbreviations } \\
\hline$D P$ & Diaminopropane \\
\hline ChlTGase & Chloroplast transglutaminase \\
\hline$C P s$ & $\begin{array}{l}\text { Proteins of chlorophyll-protein complexes } \\
\text { transducing excitation energy }\end{array}$ \\
\hline LHCII & $\begin{array}{l}\text { Antenna proteins of light-harvesting } \\
\text { chlorophyll } a / b \text {-protein complex }\end{array}$ \\
\hline$P U$ & Putrescine \\
\hline
\end{tabular}




$\begin{array}{ll}\text { REST } & \text { Relative expression software tools } \\ S D & \text { Spermidine } \\ S M & \text { Spermine } \\ \text { TGase } & \text { Transglutaminase }\end{array}$

\section{Introduction}

Transglutaminases (TGases, E.C. 2.3.2.13) are intracellular and extracellular enzymes that catalyze the posttranslational modification of proteins by establishing $\varepsilon$-( $\gamma$-glutamyl) lysine isopeptide bonds and the covalent conjugation of polyamines to endo-glutamyl residues of protein substrates (Lorand and Graham 2003; SerafiniFracassini and Del Duca 2008; Serafini-Fracassini et al. 2009). The few plant TGases sequenced to date have little sequence homology with the best-known animal enzymes, except for the catalytic triad; however, these TGases may share structural homology (Beninati et al. 2013; Della Mea et al. 2004a; Villalobos et al. 2004). Plant TGases, similar to their animal counterparts, are calcium-dependent, possess the ability to produce $\gamma$-glutamyl polyamine derivatives, and are also recognized by animal TGase antibodies (Beninati et al. 2013; Sobieszczuk-Nowicka et al. 2007, 2008, 2009). Plant TGases are involved in the growth and differentiation processes and are related to fertilization, greening, pollen germination, abiotic and biotic stresses (Del Duca et al. 2007; Della Mea et al. 2007; Dondini et al. 2001; Iorio et al. 2008; Serafini-Fracassini et al. 2002; Sobieszczuk-Nowicka et al. 2007, 2008).

TGase activity has been detected in algae as well as in angiosperms in various organs and subcellular compartments, and a role of chloroplast transglutaminases (ChlTGases) in the dynamic regulation of chloroplasts structure has been especially well documented. ChlTGases have been found mainly via immunodetection in maize callus and cucumber cotyledons, as well as in the leaves of barley, potato, tomato, Arabidopsis thaliana, Helianthus tuberosus, and Nicotiana tabacum (Serafini-Fracassini and Del Duca 2008). Villalobos et al. (2004) demonstrated that ChlTGases may be involved in the regulation of the ratio of grana thylakoids to stroma thylakoids. The architecture of the thylakoids is a major factor affecting the functionality and efficiency of the photosynthetic apparatus. Ioannidis et al. (2009) demonstrated that the remodeling of the grana may be achieved by the over-expression of a ChlTGase gene and suggested that this enzyme plays an important functional role in the formation of grana stacks. Available data strongly suggest that the mechanisms of thylakoid structure regulation involve polyamine binding to chloroplast proteins, mediated by ChlTGases (SobieszczukNowicka and Legocka 2014). The main representatives of polyamines in plant cells are putrescine (PU), spermidine
(SD), and spermine (SM) (Takahashi and Kakehi 2010). An increase in the ChlTGase activity in the transformed tobacco plants resulted in the enhanced incorporation of polyamines into thylakoid proteins and in increased thylakoid oppression (Ioannidis et al. 2009). It has been suggested that ChlTGases may bind polyamines to antenna proteins of light-harvesting chlorophyll $a / b$-protein complex (LHCII) to proteins of chlorophyll-protein complexes (CPs) transducing excitation energy: CP24, CP26, CP29, as well as to the larger subunit of ribulose bisphosphate carboxylase-oxygenase, thereby participating in the processes of chloroplast formation, photoprotection, and the stabilization of LHCII (Del Duca et al. 1994; Dondini et al. 2003; Margosiak et al. 1990; Sobieszczuk-Nowicka et al. 2008).

Structural changes of the chloroplasts, eventually leading to chloroplasts degradation mark the first phase of a sequential process of leaf senescence, both developmental one as well as induced by stresses (Sarwat et al. 2013). Senescence involves a highly regulated series of transformations, both cytological and biochemical, involving the cessation of photosynthesis, the disintegration of chloroplasts, the breakdown of leaf proteins, the loss of chlorophyll, and the remobilization of nitrogen and carbon compounds like amino acids, to other parts of plant (Buchannan-Wollaston et al. 2003). Finally, disruption of other organelles (nucleus and mitochondrion) takes place. Significant chromatin condensation, internucleosomal fragmentation of nuclear DNA and enhanced expression of cysteine proteases in the senescing mesophyll demonstrate that leaf senescence is a genetically defined process involving the mechanisms of programmed cell death (Buchannan-Wollaston and Ainsworth 1997; Van Doorn and Yoshimoto 2010). Interestingly, the dying process of a plant cell may be reversible as long as the functions of the chloroplasts can be restored (Van Doorn and Yoshimoto 2010). Therefore, we hypothesized that activation of ChlTGases may be important for executing the tightly regulated scenario of leaf senescence. Their likely contribution is also underscored by the participation of polyamines in this process. Polyamines had an anti-senescing effect when added exogenously to detached barley leaves that were incubated in darkness or to senescing lettuce leaves. Treating senescing leaves with SD and SM inhibited the degradation of thylakoids and chlorophyll (Legocka and Zajchert 1999; Serafini-Fracassini et al. 2010). However, little information is available regarding the actual role of TGases in plant cell senescence. The few available studies have focused on cell death associated with both the hypersensitive reactions to pathogens and developmental petals senescence (Del Duca et al. 2007; Della Mea et al. 2007; Dondini et al. 2001; Serafini-Fracassini et al. 2002). At the same time, involvement of both TGases and polyamines in animal cell apoptosis is well documented (Fraij 2014; Griffin and Verderio 2000; Kikuchi et al. 2014; 
Lorand and Graham 2003). While their activity in growing animal cells is low, the increased TGase gene expression and protein accumulation are associated with animal cell death. A clear role for animal TGase was revealed in the formation of apoptotic bodies (Lorand and Graham 2003). Although it has been suggested that in many mammalian systems TGase is a downstream effector in the later stages of apoptosis, elevated TGase accumulation has also been connected with early apoptotic events (Fesus et al. 1989; Griffin and Verderio 2000; Piacentini and Melino 1994).

Scientific work from the leaf senescence field has focused primarily on the model plant Arabidopsis thaliana, secondly on the identification and regulation of leaf senescence and remarkably less is known about the mechanisms of the major events in this process. In light of the confirmed role of TGase in animal cell apoptosis and only limited information on the role of this enzyme in leaf senescence, we decided to investigate the activity of ChlTGases and the fate of chloroplast-associated polyamines in barley leaves. We chose a model process that we routinely use for senescence-related studies in which senescence in barley is induced by incubation in the dark (Jackowski 1996; Legocka and Szweykowska 1981; Żelisko and Jackowski 2004).

\section{Materials and methods}

\section{Plant material}

Barley (Hordeum vulgare L. 'Nagrad') seedlings were grown for 7 days on soil under controlled conditions (day/ night $16 / 8 \mathrm{~h}, 23{ }^{\circ} \mathrm{C}$, light intensity $150 \mu \mathrm{mol} \mathrm{m} \mathrm{m}^{-2} \mathrm{~s}^{-1}$, $60 \%$ humidity) (the material for the day 0 sample was then collected). Light limitation initiated the onset of senescence and allowed the leaves to senesce in the darkness for 3, 5, 7,10 , or 12 days. Plastid isolation was performed following the procedure described previously (Sobieszczuk-Nowicka et al. 2008) by a protocol based on a differential centrifugation of leaf homogenate. The intactness and purity of the isolated plastids were evaluated by phase contrast microscopy as well as by enzymatic and immunological approaches (glutamate dehydrogenates, a mitochondrial marker enzyme, UDP-glucose pyrophosphorylase, cytosolic marker enzyme). These analyses confirmed that the samples could be reliably used for subsequent studies.

\section{HPLC polyamine analysis}

Quantitative and qualitative analysis of polyamines was performed by HPLC method according to Marcé et al. (1995) using the Varian chromatograph. The pellet of plastids $\left(100 \mathrm{mg} \mathrm{ml}^{-1}\right)$ was suspended in $5 \%$ perchloric acid, and plastid-bound polyamines were released by hydrolysis in $6 \mathrm{M} \mathrm{HCl}$ for $18 \mathrm{~h}$ at $110{ }^{\circ} \mathrm{C}$ and then dansylated with dansyl chloride. Dansylated polyamines were collected with toluene and, after toluene evaporation, dissolved in $800 \mu \mathrm{l}$ acetonitrile. The sample $(5-20 \mu \mathrm{l})$ was applied to a column of Spherisorb $5 \mu \mathrm{m}$ ODS $2^{\circledR}(4.6 \times 100 \mathrm{~mm}$, Waters) with guard column C18 (Supelguard ${ }^{\mathrm{TM}}$ Discovery $^{\circledR}$

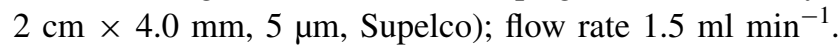
Gradient elution was performed with acetonitrile (solvent A) and water (solvent B): 0-4 min, $70 \% \mathrm{~A}$; 4-5 min, 70-100\% A; 5-9 min, $100 \%$ A; 9-10 min, 100-70\% A; $10-15 \mathrm{~min}, 70 \% \mathrm{~A}$. The flow of dansylated, polyamines was monitored using a fluorescence detector-Prostar 363 (excitation at $252 \mathrm{~nm}$, emission at $500 \mathrm{~nm}$ ). Retention times of the different polyamines were as follows: $1.8 \mathrm{~min}$ for DP, $2.2 \mathrm{~min}$ for PU, $3.35 \mathrm{~min}$ for DH (diaminoheptane, internal reference), $5.46 \mathrm{~min}$ for SD and $6.63 \mathrm{~min}$ for SM.

\section{TGase protein identification}

Immunocytochemistry and autoradiography were performed as described by Sobieszczuk-Nowicka et al. (2008). For protein identification, the anti-TGase antibody (RB060, Ab-4, Neo-Markers ${ }^{\mathrm{TM}}$, Fremont, CA, USA) was used.

\section{TGase activity assays}

Colorimetric assay of TGase activity. The biotin-cadaverine incorporation assay was carried out as described by Lilley et al. (1998). Endogenous TGase activity in isolated chloroplasts was measured as covalent binding of biotinylated cadaverine to endo-glutamyl residues of $N^{\prime}, N^{\prime}$ dimethylcasein (DMC) $(10 \mathrm{mg} / \mathrm{ml})$ used to precoat the assay microplate. The measurement of enzyme activity was preceded by overnight dialysis $(10 \mathrm{mM}$ Tris, $\mathrm{pH} 8.5$ and $1 \mathrm{mM} 2$-mercaptoethanol) and performed with $5 \mathrm{mM} \mathrm{Ca}^{2+}$; replaced by $1 \mathrm{mM}$ EDTA in the negative control.

For the radiometric assay, the measurement of enzyme activity was preceded by an overnight dialysis $(10 \mathrm{mM}$ Tris, $\mathrm{pH} 8.5$, and $1 \mathrm{mM}$ 2-mercaptoethanol) and performed with $2.5 \mathrm{mM} \mathrm{Ca}^{2+}$. The isolated plastids were assayed in the presence of $\left[{ }^{3} \mathrm{H}\right] \mathrm{PU}$ or $\left[{ }^{3} \mathrm{H}\right] \mathrm{SD}$, which provided the primary amino groups used as the acyl acceptors of the glutamyl residues of the plastid proteins (Dondini et al. 2003). The assay was performed for $1 \mathrm{~h}$ at $37{ }^{\circ} \mathrm{C}$ in $100 \mathrm{mM}$ Tris (pH 8.5) containing per sample $200 \mu \mathrm{g}$ plastid proteins, $10 \mathrm{mM}$ DTT, $3 \mu \mathrm{Ci}$ PU or SD (the specific activity of PU was $40 \mathrm{Ci} \mathrm{mmol}^{-1}$ and that of SD was $34.82 \mathrm{Ci} \mathrm{mmol}^{-1}$ ) and $200 \mu \mathrm{M}$ unlabeled PU or SD, respectively. The final volume was adjusted to $300 \mu \mathrm{l}$ with Tris. The reaction was halted by $5 \%$ (w/v) TCA, which also contained $2 \mathrm{mM}$ unlabeled PU or SD (Del Duca et al. 1994). The pigments were removed by anhydrous acetone. The incorporation of 
labeled PA was measured using a Beckman LS 6500 multipurpose scintillation counter.

Mass spectrometry-based identification of TGase protein substrates

The $\left[{ }^{3} \mathrm{H}\right] \mathrm{PU}$ - or $\left[{ }^{3} \mathrm{H}\right] \mathrm{SD}$-conjugated plastid proteins were labeled and imaged as described by Sobieszczuk-Nowicka et al. (2008). The protein bands were manually excised from the gels, transferred to Eppendorf tubes, destained, washed, and in-gel digested as follows. The gel pieces were rinsed twice in $100 \mu \mathrm{l}$ washing buffer $[50 \mathrm{mM}$ $\mathrm{NH}_{4} \mathrm{HCO}_{3} / 100 \%$ acetonitrile (vol. 1:1)] for 15 min, dehydrated in $100 \% \mathrm{ACN}$, and then reduced with $10 \mathrm{mM}$ DTT in $50 \mathrm{mM} \mathrm{NH} \mathrm{NCO}_{3}$ at $56{ }^{\circ} \mathrm{C}$ for $45 \mathrm{~min}$ and alkylated with $55 \mathrm{mM}$ IAA in $50 \mathrm{mM} \mathrm{NH} \mathrm{HCO}_{3}$ at room temperature for $30 \mathrm{~min}$ in the dark. After the dehydration and drying, the gel pieces were rehydrated by the addition of $10 \mu$ digestion buffer [ $25 \mathrm{mM}$ ammonium bicarbonate and $0.2 \mu \mathrm{g}$ sequencing-grade trypsin (Promega)]. The digestion was performed overnight at $37^{\circ} \mathrm{C}$. The peptides were extracted with $10 \% \mathrm{ACN}$. The digested proteins were identified using a MALDI-TOF/TOF mass spectrometer. The acquisition of the MALDI spectra used a ultrafleXtreme mass spectrometer (Bruker Daltonics, Germany) that was operated in reflector mode, using delayed ion extraction. The positively charged ions in the $820-3,500 \mathrm{~m} / \mathrm{z}$ range were analyzed. A total of $0.5 \mu \mathrm{l}$ of the sample was co-crystallized with the CHCA matrix and spotted directly on the MALDI AnchorChip target (Bruker Daltonics). To validate the data, an external calibration was performed with a standard mixture of peptides. Flex control v. 3.3 software was used for the acquisition of spectra, and all further data processing was carried out using Flex analysis v. 3.3 software. The spectrometric analysis was performed in an automatic dependent mode, using Bio Tools 3.2. A maximum of ten precursor ions per sample were chosen for the MS/MS analysis. The monoisotopic peptide masses were assigned and used for database research. The protein database searches, using the combined PMF and MS/MS datasets, were performed using Bio Tools 3.2 software (Bruker). The proteins were identified using the Mascot (Matrix Science, London, UK) program against the SwissProt and NCBI databases. The protein search was performed using the following search parameters: mass tolerance $\pm 0.5 \mathrm{Da}$, one allowed missed cleavage, cysteine treated with iodoacetamide to form carbamidomethyl-cysteine and methionine in the oxidized form.

Identification of polyamine derivatives

The polyamine derivatives that covalently bound to the proteins were identified in the TCA-insoluble fractions obtained from the TGase radiolabeled assay, as described by Beninati et al. (2013), except that the Jasco HPLC instrument was used for chromatographic separation.

\section{Real-time RT-PCR}

The frozen barley shoot samples from four biological replicates of the dark-induced senescence experiment (independent cultivations) were used for time course analysis. For each time point, RNA samples were prepared from a pool of $\sim 30$ plants per replicate. The RNA isolation, DNase digestion, quality analysis, reverse transcription, and qPCR assays were performed as described by Kulik et al. (2012) with the following modifications. The Rotor-GeneQ (Qiagen) qPCR system was used. The qPCR reaction was performed for 40 cycles. The working concentration of the cDNA samples was adjusted so that the amplicons would lie within the non-inhibitory concentration range defined by the 6-point standard curve which was prepared by serial dilution of a pool of equal concentrations of each cDNA, according to the guidelines presented by Gallup and Ackermann (2008). The primer sequences for the HvPng1-like expression assay were designed using Primer-BLAST (NCBI): forward (5'-CAGGCGGAAGAAGAGGCACT- $3^{\prime}$ ), and reverse (5'-ACTTCAGAACCTGGCGCATGTA- ${ }^{\prime}$ ). Each sample was run in three technical replicates. The expected size and uniformity of the product (117 bp) were verified by a melting curve analysis (60$95{ }^{\circ} \mathrm{C}$ range with $0.5^{\circ} \mathrm{C}$ steps) following each qPCR assay and by agarose gel electrophoresis.

\section{Statistical analysis}

The differences in the measured parameters were analyzed for statistical significance using one-way analysis of variance (ANOVA) and Tukey-Kramer Multiple Comparison Test. Means were considered as significantly different at $p$ value $<0.01$.

The statistical analysis was performed using Standard Method STATISTICA software (Stat Soft Inc., Tulsa, OK, USA). For the analysis of the real-time RT-PCR data, Ct values were calculated with the Rotor-GeneQ software and the data for technical replicates were averaged. Relative gene expression was estimated based on data from four biological replicates, using the relative expression software tool (REST 2009 V2.0.13, QIAGEN, Hilden, Germany) which is a dedicated standalone software for estimation of gene expression and statistical analysis. REST 2009 V2.0.13 corrects data for exact PCR efficiencies and addresses issues surrounding the measurement of uncertainty in expression ratios by introducing randomization and bootstrapping techniques (Pfaffl et al. 2002). The expression ratios were tested for significance $(p<0.05)$ by 
a Pair Wise Fixed Reallocation Randomisation Test implemented in REST with 10,000 iterations.

Bioinformatic analysis

The sequences of plant proteins that were previously reported to possess TGase activity were used for blastp and tblastn searches against the NCBI/GenBank and MaizeGDB databases, and the taxonomy term-based specific filters were applied when necessary (Altschul et al. 1997, 2005). The UniGene sequences were identified in the NCBI/UniGene database and assembled into contigs using a standalone version of the CAP3 assembler (Huang and Madan 1999). The NCBI/CDD database was searched to identify protein domains (Marchler-Bauer et al. 2011). Multiple sequence alignments were performed using the ClustalW and Multalign web-based services (Corpet 1988; Larkin et al. 2007). An Affymetrix probeset corresponding to the HvPngl-like cDNA sequence (Contig18871_at) was identified in the PLEXdb database. The expression profiles of HvPngl-like were analyzed according to the publically available results of microarray experiments via the Genevestigator database (Hruz et al. 2008) and PLEXdb database (Druka et al. 2006).

\section{Results}

Detection of ChlTGases in green and senescing barley leaves

To verify whether the capacity of plant to control senescence might be linked to ChlTGase-mediated changes in chloroplast architecture, we first aimed to detect ChlTGases in plastids.

We observed changes in the suborganellar localization of the ChlTGases during the chloroplast-to-gerontoplast transformation and during the final degradation of the gerontoplast that was associated with the senescence process (Fig. 1). The primary changes in the ultrastructure of the chloroplasts during senescence involved thylakoid membrane destacking and the appearance of plastoglobuli (days 3-5, Fig. 1b, c). Over time, parallel destacked membranes were observed and eventually disappeared by the end of the process, which was accompanied by an increase in the number and size of the plastoglobuli (days 7-12, Fig. 1df). Gold labeling revealed the presence of ChlTGases at all stages of dark-induced chloroplast degradation. Initially, the enzyme specifically localized to the thylakoids, where it persisted until their disassembly (days 0-10, Fig. 1a-e, 1A1-E1), but as the degradation advanced, the ChlTGases were detected in the stroma as well (days 5-12, Fig. 1c-f, 1C2-E2).
Changes in the level of plastid-associated polyamines during senescence of barley leaves

The presence of ChlTGases in barley chloroplasts associated with the senescence progress indicates that the thylakoid membrane disassembly may be related to structural changes of plastid proteins mediated by polyamines. We therefore determined the levels of plastid membrane-associated polyamines: PU SD, SM and diaminopropane (DP, which is a product of oxidation of SD, SM, and indirectly also of PU), in each stage of leaf senescence (Fig. 2). The most abundant polyamine was PU and its level steadily increased until day 7 of senescence, when it reached a maximum level (170\% of the control level, measured at the senescence induction onset-day 0). Afterwards, we observed a gradual decrease in the level of PU, however, it was still above the control level by $38 \%$ at day 10 and by $11 \%$ at day 12 (Fig. 2a).

The control level of SD was about 47 times lower than PU and it increased dynamically during the chloroplast senescence, reaching its maximum level at day $10(350 \%$ of the control value). The highest increase was noticeable between days 0 and 3 as well as between days 5 and 7, with a rise of about $50 \%$ between consecutive time points in each case. At day 12 the amount of SD dropped by about $42 \%$ of its maximum level and was still much higher than in the control (Fig. 2b).

The level of SM was lower than PU by two orders of magnitude. Unlike other polyamines, the SM amount dropped throughout the entire period of leaves senescence, achieving 3.5 times reduction of its control level at the last analyzed time point. We observed the strongest reduction in the level of SM between days 5 and 7 (from $70 \%$ down to $43 \%$ of the control level) (Fig. 2c).

The amount of DP showed a step wise increase in the chloroplasts of senescing barley leaves, observable between days 0 and 3, when it reached $254 \%$ of the control activity as well as between days 7 and 10, when it reached its maximum at $381 \%$ of the control activity. Afterwards, the level of DP dropped but was still as much as $208 \%$ of the control activity, at day 12 (Fig. 2d).

\section{Changes in the ChlTGase activity during senescence}

Having confirmed the presence of ChlTGases and modulation of polyamine levels in senescing barley chloroplast, we turned to the analysis of barley ChlTGases activity. We used colorimetric and radiometric methods to monitor the changes in the ChlTGases total activity during dark-induced leaf senescence. In the first assay, the TGase enzymatic activity was measured as the ability to conjugate the exogenous substrates biotin-cadaverine to $N, N^{\prime}$ dimethylcasein in a calcium-dependent manner. Using this 
Fig. 1 Immunolocalization of barley ChlTGase during senescence-associated leaf chloroplast degradation. a $A 1$ and $A 2$ ultrastructure of green (day 0), b $B 1$ and $B 2$ and, $\mathbf{c} C 1$ and $C 2$, dark-induced initiation ing senescence (days 3 and 5, respectively), $\mathbf{d} D 1$ and $D 2$, complete thylakoid destacking, visible as parallel destacked membranes, accompanied by an increased number of plastoglobuli (day 7), e $E 1$ and E2 disappearance of thylakoid membrane with the concomitant appearance of large plastoglobuli (day 10), f total gerontoplast degradation (day 12). Enlargement of thylakoid and stroma areas are presented in $A 1-E 1$ and in $A 2-E 2$, respectively. The gold particles (arrowheads) indicate TGase localization. $T$ thylakoid, $S T$ stroma, $P G$ plastoglobuli leaf chloroplast in the control of thylakoid destacking dur-
A

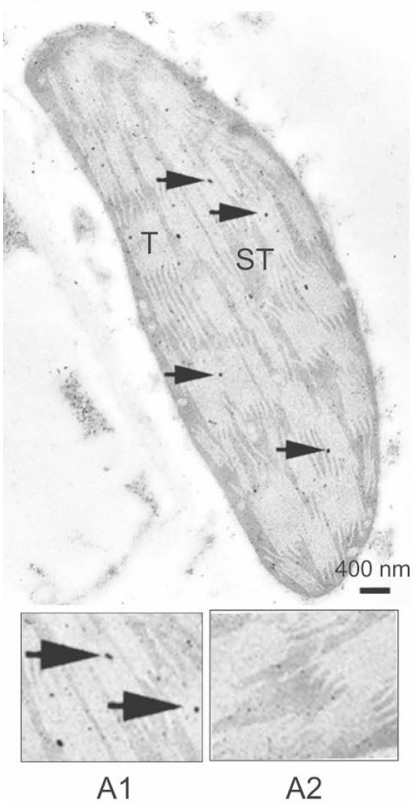

D

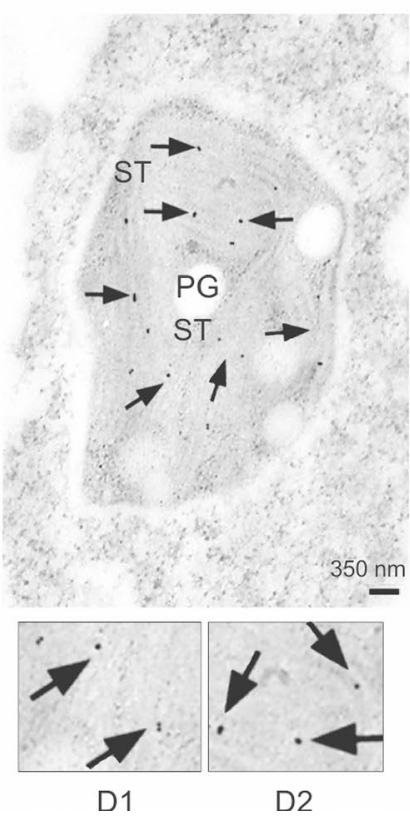

B

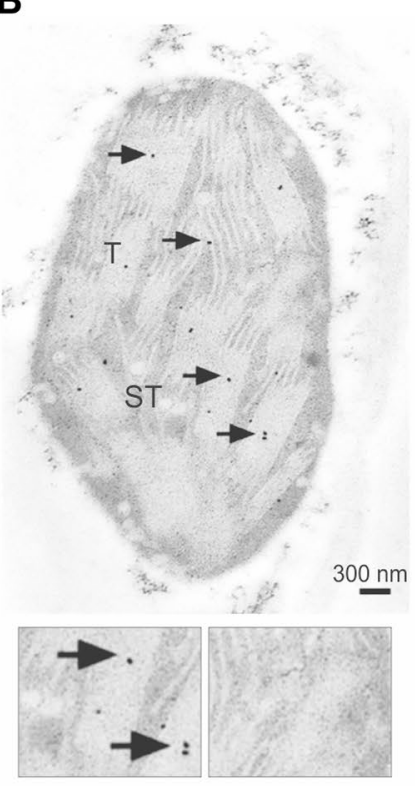

B1

E

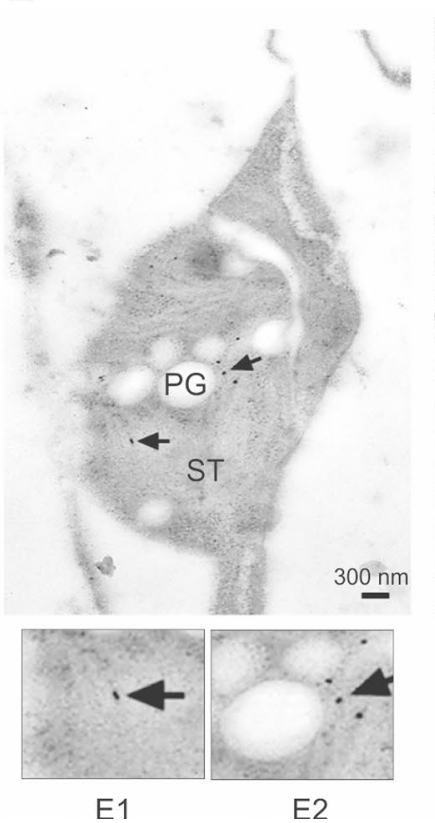

C

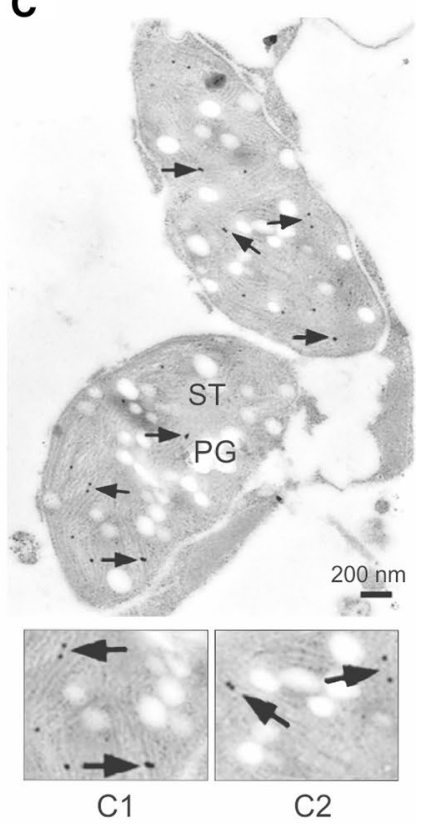

$\mathbf{F}$

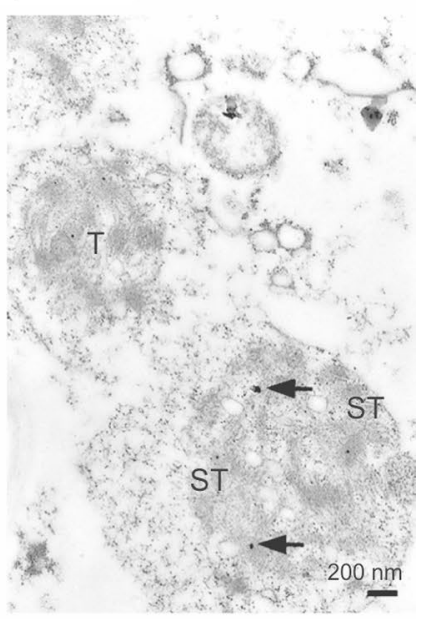

assay, we observed a continuous increase in the TGase activity until day 10 of senescence, when it reached $0.26 \mathrm{U} /$ $\mathrm{mg}$ protein $(412 \%$ of the activity measured on day 0 ) (Fig. 3a). After day 10, a rapid decline in the activity of the enzyme was observed, and the activity achieved $50 \%$ of the maximal value on day 12 .

In the second (radiometric) assay, the ChlTGase activity was estimated based on the rate of the radiolabeled polyamine conjugation to endogenous proteins. Our results suggested that the levels of PU and SD (but not $\mathrm{SM}$ ) bound to the thylakoid fractions of the barley leaves

increased during the early stages of barley leaf senescence. We therefore conducted a time course of the changes in the levels of $\left[{ }^{3} \mathrm{H}\right] \mathrm{PU}$ or $\left[{ }^{3} \mathrm{H}\right] \mathrm{SD}$ incorporation into the endogenous plastid proteins to ascertain which of the two polyamines is most efficiently conjugated by the ChlTGases during senescence (Fig. 3b). The amounts of bound $\left[{ }^{3} \mathrm{H}\right]$ $\mathrm{PU}$ and $\left[{ }^{3} \mathrm{H}\right] \mathrm{SD}$ were equal before the induction of the senescence process and did not significantly change after 3 days of incubation in the darkness. A significant increase in the polyamine conjugation was observed on day 5 and reached a maximum on day 7 ; however, the $\left[{ }^{3} \mathrm{H}\right] \mathrm{PU}$ peak 

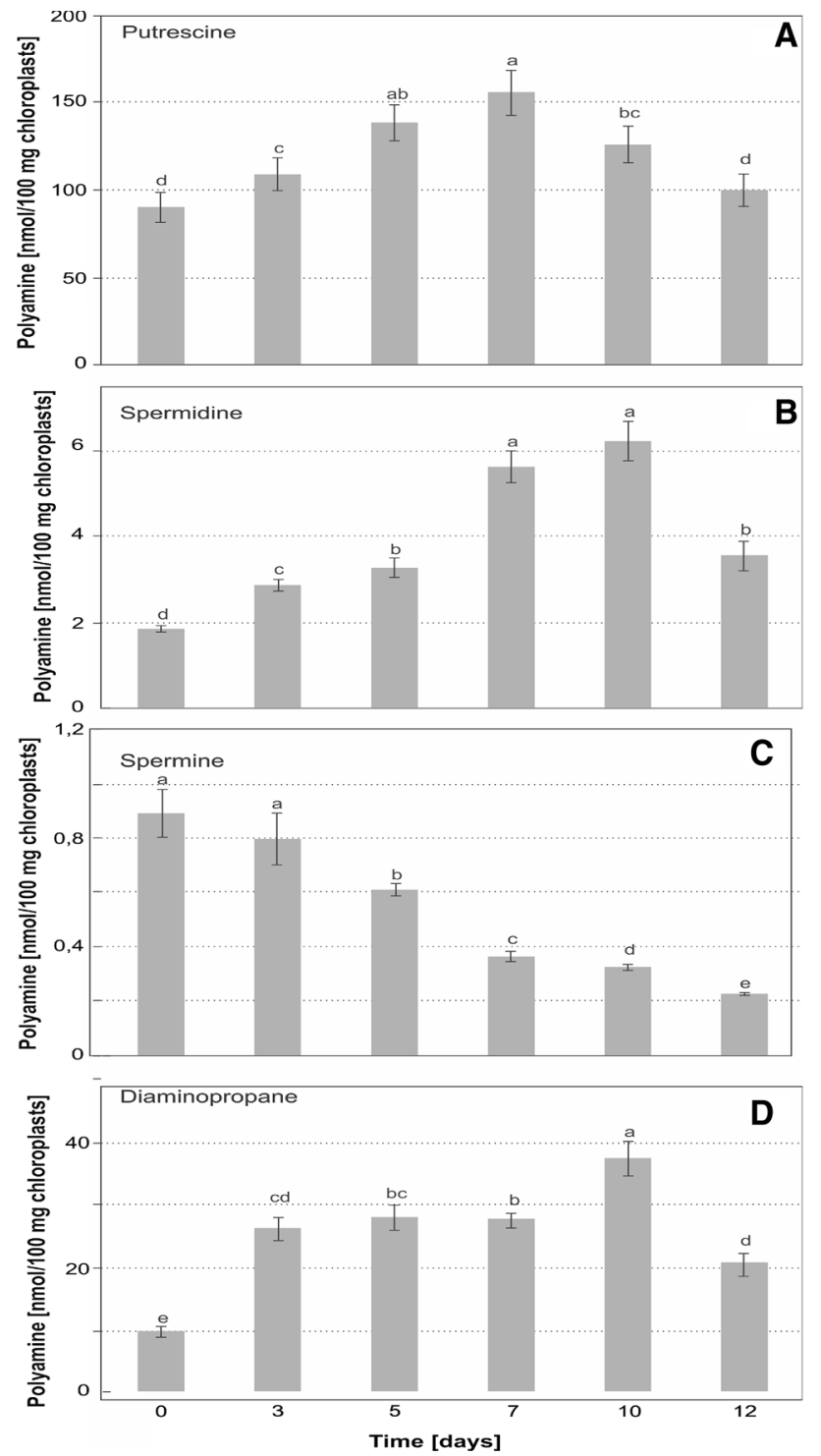

Fig. 2 Changes in the level of plastid-associated polyamines: putrescine (a), spermidine (b), spermine (c) and diaminopropane (d) determined during dark-induced senescence of barley leaves. The differences in the measured parameters were analyzed for statistical significance using one-way analysis of variance (ANOVA) and the Tukey-Kramer Multiple Comparison Test $(n=9, p<0.01)$. The same letter on bars indicates that there was not significant differences between the means

was much higher-more than $270 \%$ of the control level (day 0) - while the maximal amount of bound $\left[{ }^{3} \mathrm{H}\right] \mathrm{SD}$ was approximately $200 \%$ of the control. On day 10 , the level of the conjugated SD dropped below the level of the control, while the level of the conjugated PU remained approximately two times higher than it was before the onset of senescence and eventually decreased below the control level on day 12 .

PU was revealed to be the major polyamine involved in the post-translational modifications of the plastid
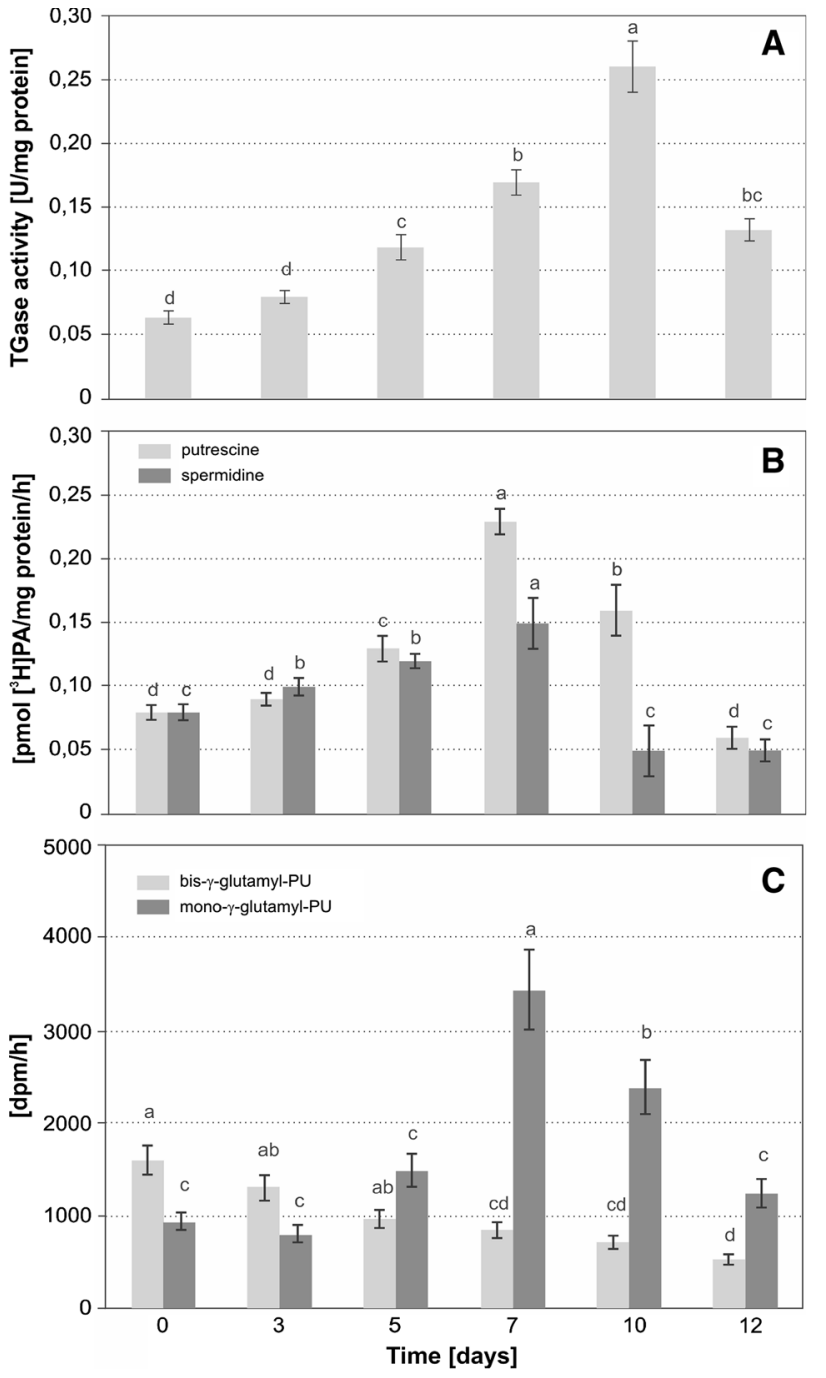

Fig. 3 a biotin-cadaverine binding to $N, N^{\prime}$-dimethylcasein (colorimetric assay), b $\left[{ }^{3} \mathrm{H}\right] \mathrm{PU}$ and $\left[{ }^{3} \mathrm{H}\right] \mathrm{SD}$ conjugation to plastid proteins (radiometric assay), c levels of mono- and bis- $\left(\gamma\right.$-glutamyl)- $\left[{ }^{3} \mathrm{H}\right] \mathrm{PU}$ derivatives. The differences in the measured parameters were analyzed for statistical significance using one-way analysis of variance (ANOVA) and Tukey-Kramer Multiple Comparison Test (a, $n=9, \mathbf{b}$, c, $n=6, p<0.01$ ). The same letter on bars indicates that there was no significant differences between the means

proteins, and we therefore analyzed the distribution of protein-bound mono- and bis-( $\gamma$-glutamyl)-PU derivatives in the plastids of the senescing barley leaves (Fig. 3c). The senescence-associated changes in the amount of mono-( $\gamma$-glutamyl)-PU mirrored those observed for total PU conjugation (presented in Fig. 3b), with a strong peak on day 7 ( $365 \%$ of the control level), and a subsequent decrease on days 10-12. At the same time, the level of bis-( $\gamma$-glutamyl)-PU, which was the dominant PU derivative on day 0 , continually decreased through the entire senescence period to approximately $45 \%$ of the initial amount. 


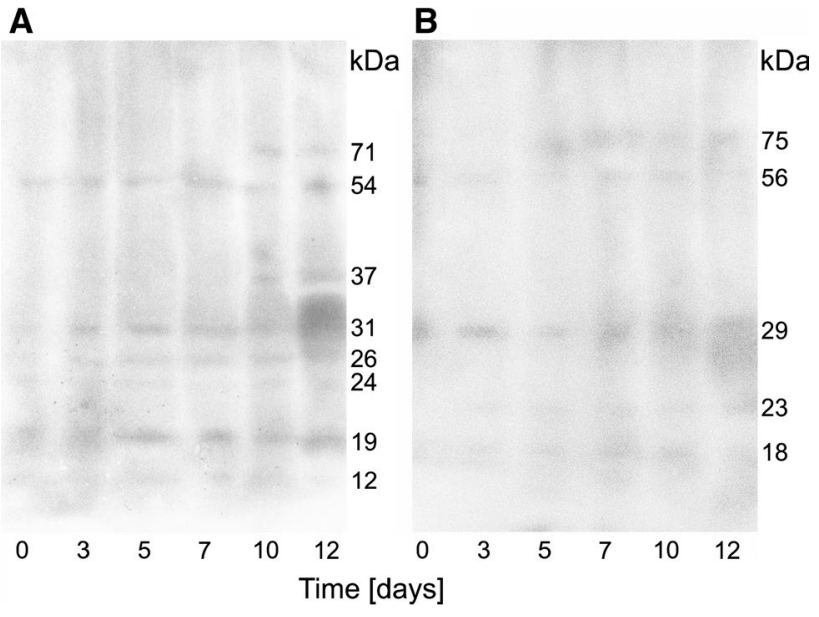

Fig. 4 Autoradiography of SDS gel electrophoresis of barley plastid proteins isolated from dark-induced senescing leaves and incubated in the presence of $\left[{ }^{3} \mathrm{H}\right] \mathrm{PU}(\mathbf{a})$ and $\left[{ }^{3} \mathrm{H}\right] \mathrm{SD}(\mathbf{b})$

\section{Plastid proteins as TGase substrates}

Once the TGase catalytic activity was detected in senescing chloroplasts and we confirmed the presence of physiological protein substrates for ChlTGases, we aimed to identify the plastid proteins modified by ChlTGase-mediated crosslinking. The autoradiography of the SDS-PAGE separated plastid proteins, which were bound to $\left[{ }^{3} \mathrm{H}\right] \mathrm{PU}$ and $\left[{ }^{3} \mathrm{H}\right] \mathrm{SD}$, revealed 8 and 5 protein bands, respectively $(71,54,37$, $31,26,24,19$, and $12 \mathrm{kDa}$ for PU and 75, 56, 29, 23, and $18 \mathrm{kDa}$ for SD; see Fig. 4). Both polyamines were conjugated to multiple proteins that are involved in the organization and regulation of the photosystem apparatus (details of the MS/MS identification of the protein bands are presented in Table 1) and were detected in all time points, including in the control. Histone-like protein $(12 \mathrm{kDa})$ was observed from days $0-7$, whereas peroxiredoxin and class I heat shock protein ( 23 and $18 \mathrm{kDa}$, respectively) were not detected before senescence induction and appeared as TGase substrates, beginning on day 3. IAA (indoleacetic acid)-amino acid hydrolase (75 kDa) was observed beginning on day 5 and two proteins, starch synthase $(71 \mathrm{kDa})$ and ent-copalyl diphosphate synthase $(37 \mathrm{kDa})$, were visible only in the late senescence stages (beginning on day $10)$.

Identification and expression analysis of AtPnglp homologue in barley

To date, the cDNA sequences of two apparently non-orthologous genes whose products possess TGase activity (as documented by in vitro or in vivo experiments) have been described in plants. The first gene codes for the Arabidopsis AtPng1p protein (TAIR locus AT5G49570) (Della Mea et al. 2004a). The other report concerns the highly similar Zea mays TGases TGZ15 and TGZ21, which were discovered by the immunoscreening of a cDNA library (Villalobos et al. 2004). Considering that over 22,500 full-length cDNAs that were derived from various barley cDNA libraries have been recently added to available sequence resources (Matsumoto et al. 2011), a computational search for barley proteins with a high homology to AtPng1p or TGZ15/TGZ21 proteins was performed (Supplementary Text, Supplementary Figures S1-S6, Supplementary Table S1). As a result, a 777 aa long protein exhibiting a high degree of similarity to the AtPng1p reference protein sequence has been identified. It possesses a conserved core domain with a catalytic triad, characteristic of TGases. Throughout the article, we will refer to this protein as HvPng1-like. As we were not able to identify any protein homologue of maize TGZ15 and TGZ21 in the public databases nor did we find the corresponding coding sequence in the reference maize genomic DNA sequence, we focused on the functional analysis of only the HvPngl-like gene.

In barley, HvPngl-like is expressed at a medium level and does not show major fluctuations throughout the plant development (Druka et al. 2006) (Supplementary Figure S7). We analyzed expression changes of the HvPng1-like gene during the dark-induced senescence of barley leaves in four independent biological replicates. We repeatedly observed increase in HvPngl-like transcript amount, associated with the senescence progress, although the level and the duration time of gene induction varied between the replicates (Supplementary Figure S8). The averaged profile of HvPng1-like expression is presented in Fig. 5. The level of transcript increased at the onset of the senescing process (day 3), remained elevated up to day 10 , and then dropped on day 12 , with significant changes observed on day 3,5 , and 7.

\section{Discussion}

The senescence is a natural developmental phase in the life of plant. It can be also induced by various types of stress, leading to death of plant parts, for example leaf. The senescence proceeds through a series of synchronized events and is tightly regulated by a variety of internal factors, including plant hormones (Sarwat et al. 2013). Here we show that physiological and structural changes of chloroplasts, associated with the dark-induced senescence of barley leaves, involve polyamine conjugation and modification of chloroplast proteins, accompanied by modulation of barley ChlTGases localization and activity. Earlier studies of senescing barley leaves showed that the level of the $78 \mathrm{kDa}$ TGase was lower when the samples were incubated with cytokinin, a phytohormone known for its anti-senescence 


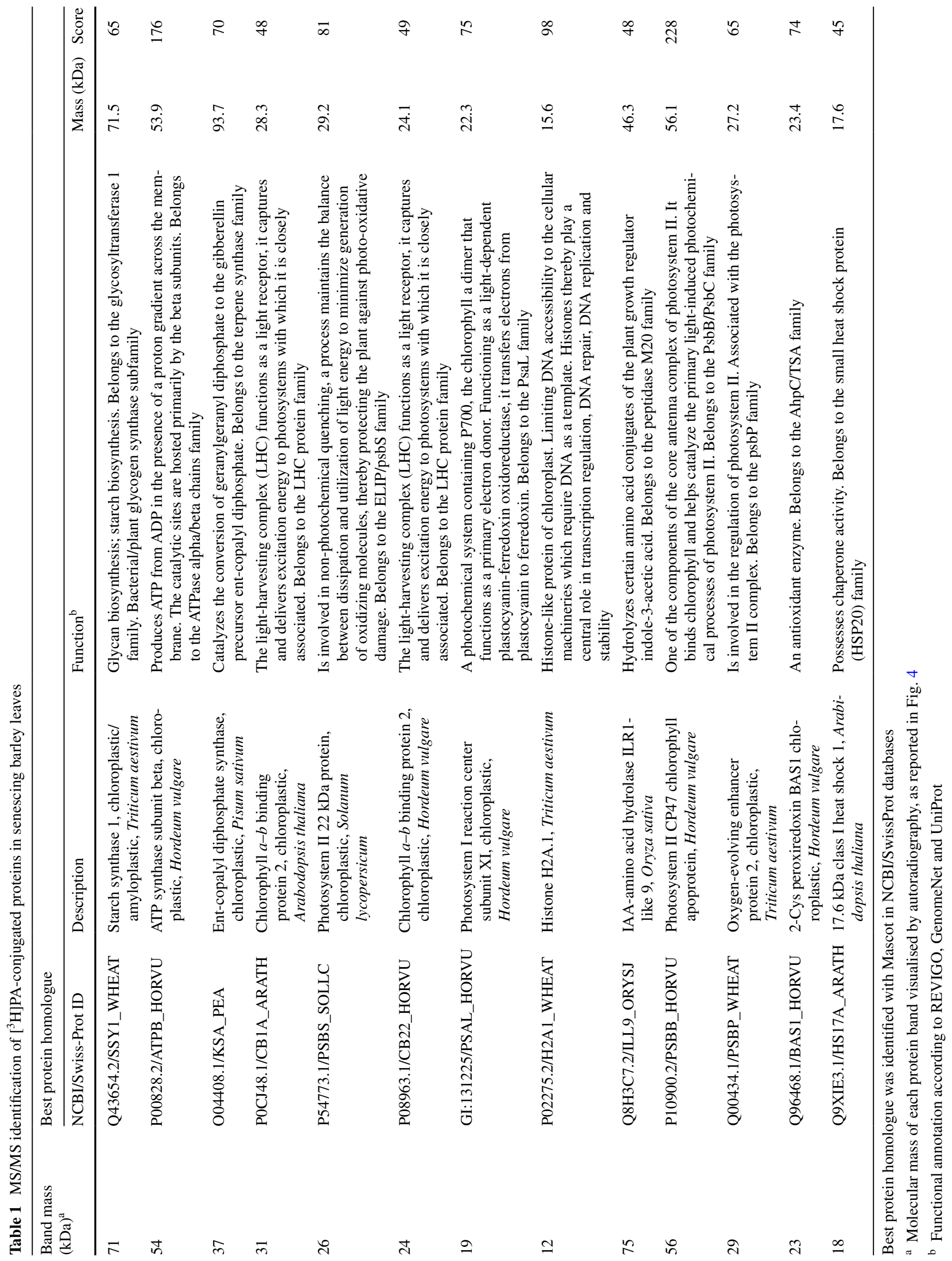


properties (Sobieszczuk-Nowicka et al. 2009). Using an anti-TGase antibody, we detected three polypeptides in the chloroplasts of senescing barley leaves with the following masses 33, 58, and $78 \mathrm{kDa}$ (Sobieszczuk-Nowicka et al. 2009). This conclusion is now supported by suborganellar detection of ChlTGases. The plastid enzyme might be involved in the stabilization of the plastid structure under stress conditions (darkness) and/or in its rearrangement during the chloroplast-to-gerontoplast transformation, similar to how it contributes to the conversion of an etioplast into a chloroplast (Sobieszczuk-Nowicka et al. 2008).

An increase in the activity of TGase was observed until day 7 , in the presence of $\left[{ }^{3} \mathrm{H}\right] \mathrm{PU}$ and $\left[{ }^{3} \mathrm{H}\right] \mathrm{SD}$. The upward trend (until day 10) was also observed during the colorimetric analysis of the ChlTGase activity. The shift of the maximum enzyme activity peak between the two methods most likely resulted from the different availability of protein substrates for the enzyme. When measuring the TGase activity using the radiometric method, the enzyme recognized the endogenous plastid proteins and not the exogenously applied substrate, as in the colorimetric assay. Therefore, as the degradation of the chloroplast structures advanced, a decrease in the plastid proteins might have been the limiting factor for the later time points (days 10 and 12) of the radiometric assay. Moreover, the senescence-associated changes in the amount of mono- and bis-( $\gamma$-glutamyl)-PU corroborated the studies of the Serafini-Fracassini team run on tobacco corolla which showed that during petals senescence the decrease in the bis- $(\gamma$-glutamyl $)-\mathrm{PU}$ and bis- $(\gamma-$ glutamyl)-SD occurs, whereas the amount of mono- $(\gamma$ glutamyl)-PU increased (Serafini-Fracassini et al. 2002).

In the senescing barley leaves, changes in ChlTGase amount and localization paralleled the changes in the level of plastid membrane-bound polyamines: PU and SD, the levels of which continuously increased till day 7-10 of the process. Polyamines, which are low molecular weight cations synthesized in almost all biological systems, are implicated in a divergent array of processes and are believed to be important modulators of plant growth and development (Walden et al. 1997). Their intracellular titers must be strictly regulated (Moschou et al. 2008; Takahashi and Kakehi 2010). High polyamine levels have been observed in actively growing tissues (Mattoo et al. 2010), while their amount was suppressed in senescing tissues, both in the developmental and stressinduced senescence processes (Altman and Bachrach 1981; Sobieszczuk-Nowicka et al. 2009).

An increase in TGase activity, in cooperation with enhanced polyamine biosynthesis may result in the modification of a protein charge and conformation through the formation of cross-links within the same protein or between two or more proteins, which are then active in senescence. These cross-links contribute to the stability of protein structures and changes in their solubility, and ability to

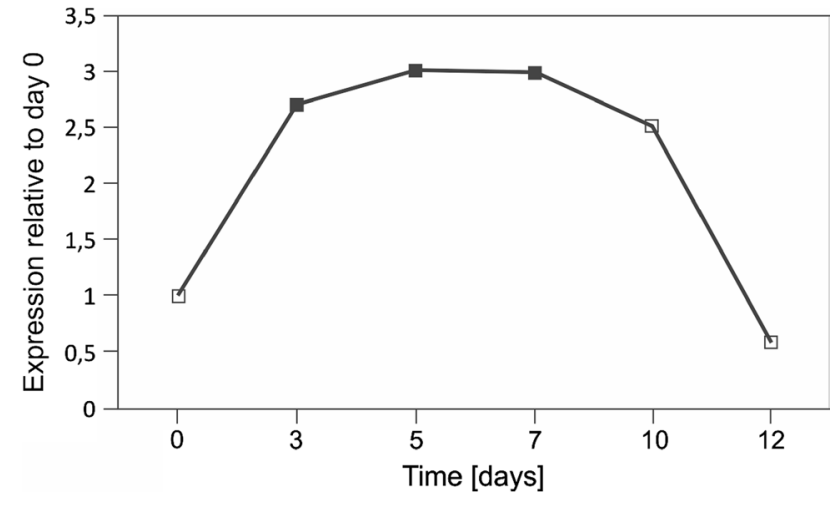

Fig. 5 The time course of HvPngl-like expression during the 12 days of senescence (data averaged from four biological replicates). Significance of the relative changes in gene expression (compared to day 0) was tested with Pair Wise Fixed Reallocation Randomisation Test (Pfaffl et al. 2002). Significant changes were observed at day $3(p=0.001)$, day $5(p=0.003)$, and day $7(p=0.002)$ and are marked as black filled squares

interact with other molecules (Lorand and Graham 2003; Serafini-Fracassini and Del Duca 2008; Serafini-Fracassini et al. 2009). Conversely, the modification or change in the protein availability elucidated by initiated organelle degradation could affect the PU and SD linkage, with a possible impact on the protein activity and senescence progress. Regardless of the mechanism involved, the detection of polyamines (PU and SD) covalently linked to glutamyl residues of specific endogenous proteins demonstrates the selectivity of TGase action; therefore, a physiological role might be ascribed to this enzyme in the senescence context. The MS/MS identification of the proteins bound to $\left[{ }^{3} \mathrm{H}\right] \mathrm{PU}$ and $\left[{ }^{3} \mathrm{H}\right] \mathrm{SD}$ showed that the protein components of both photosystems were modified by ChlTGase activity. The apoproteins of the chlorophyll $a / b$ antenna complex have already been suggested as the substrates of ChlTGases in mature leaves (Del Duca et al. 1994; Della Mea et al. 2004b; Dondini et al. 2003). Recently, the LC-MS mass spectrometry identification of protein complexes indicated also that TGZ proteins form part of a specific photosystem II protein complex, which includes LHCII, ATPase, and $\mathrm{pSbS}$, that plays a role in energy-dependent quenching that increases thermal dissipation of excess absorbed light energy in the photosystem (Campos et al. 2010).

The other identified protein, histone, which is also known animal TGase substrate (Ballestar et al. 1996), may correspond to the chloroplast histone-like protein (Kobayashi et al. 2002; Melonek et al. 2012). In accordance with the presence of histone-like proteins in plastids, in recent years, evidence about these proteins involves in regulation of plastid nucleoids morphology and compactness have been accumulated. Histone-like chloroplast protein can be either coded by the chloroplast DNA (Kobayashi 
et al. 2002) or by nuclear DNA and, which was found by fusion with GFP, to be dually targeted: to plastids and to the nucleus (Melonek et al. 2012). This result would suggest a TGase contribution in a well-known role of polyamines in DNA repair, replication or stability (Sobieszczuk-Nowicka and Legocka 2014). Most of all, we identified several stress-response proteins in the polyamine-bound fraction. The antioxidant enzymes peroxiredoxin, heat shock protein, ent-copalyl diphosphate synthase, are involved in gibberellin biosynthesis and IAA-amino acid hydrolase (Cejudo et al. 2012; Noushina et al. 2011; Van der Graaff et al. 2006; Wang et al. 2004).

None of those proteins were detected in the polyaminebound fraction before the induction of the senescence process. A combination of the proteomic data and the results of the TGase activity assays support our hypothesis that the ChlTGases and polyamines are functionally involved in the cellular mechanisms of senescence. These data also provide a logical explanation of our previous observations: the addition of the anti-senescing hormone kinetin inhibited the dark-induced increase of ChlTGase activity and inhibited the increase of polyamine accumulation in the barley thylakoid membrane fraction (Sobieszczuk-Nowicka et al. 2009).

The only membrane-bound polyamine whose level decreased during senescence was SM. Its decreasing level during chloroplast degradation could be related to the breakdown of chloroplasts and degradation of proteins of the chlorophyll $a / b$ antenna complexes to which it is bound. The released SM can be converted to polyamines with a lower molecular mass, such as PU and SD (SerafiniFracassini et al. 2010). It also cannot be ruled out that as a result of oxidative deamination SM, but also other polyamines, are the source of $\mathrm{H}_{2} \mathrm{O}_{2}$ and/or cytotoxic aldehydes, e.g. acroleins (Novakoudis et al. 2007; Takahashi and Kakehi 2010). Polyamine analysis showed an increasing level of DP. Its presence, therefore, indicates the occurrence of oxidation processes that might contribute to chloroplast degradation. It has been also suggested that monoderivative polyamines are preferred substrates for oxidases (Serafini-Fracassini et al. 2002). In this case, TGases could also indirectly stimulate the formation of reactive oxygen species in the chloroplasts and affect or execute their degradation.

The activity of ChlTGases through senescence can be controlled not only by the post-translational regulation, but also by transcription. The most studied plant gene coding for a protein with TGase activity is Arabidopsis AtPnglp. It has been shown that in conditions of undisturbed growth, the AtPnglp gene undergoes constitutive expression at a low level in all plant organs during various stages of development and under various light conditions (Della Mea et al. 2004a). We observed the same expression pattern for the HvPngl-like gene, which was computationally identified on the basis of its high sequence homology to AtPnglp. We also analyzed its expression profile during plant senescence. Our real-time RT-PCR experiments showed that expression of HvPngl-like increased as early as day 3 of senescence, when the mechanisms associated with the degradation of cell structures begin to be activated, and was up-regulated until day 10 .

In our analysis, we were not able to identify any plant cDNA/protein sequence in the public databases with fulllength amino acid sequence homology to TGZ15/TGZ21, two other TGases described previously (Villalobos et al. 2004). Despite high homology on the nucleotide level, the unique deletion of $\mathrm{G}$ in the TGZ15/TGZ21 cDNA sequences resulted in a frameshift in their amino acid sequences, and consequently, a lack of homology at their C-termini, where the TGase catalytic triad was found by Villalobos et al. (2004). Recently, the same group reported the isolation and characterization of a rice homolog of the TGZ15/TGZ21 proteins named TGO. The TGO cDNA possesses a unique $\mathrm{G}$ deletion not observed in the other available rice sequences, including the genomic sequence of rice chromosome 4 (Campos et al. 2013). The maize TGZ15/ TGZ21 and rice TGO proteins share high sequence homology $(70 \%)$, but only upstream of the $\mathrm{G}$ deletion positions, while their C-termini differ in length and sequence as well as in catalytic triad localization. However, overexpression experiments provide evidence that both proteins possess TGase activity (Campos et al. 2010, 2012, 2013; Ioannidis et al. 2009, 2012; Ortigosa et al. 2010; Villalobos et al. 2004), although their catalytic domains are not conserved.

\section{Conclusions}

In this study, we presented experimental evidence that the barley ChlTGase is activated during the dark-induced leaf senescence, which corresponds to the enhanced local TGase accumulation and activity and the increased expression level of the barley HvPngl-like gene. The ChlTGase localization within chloroplast structures, as well as the identification of post-translational modification of plastid proteins (polyamine-conjugated proteins), suggests a wide contribution of ChlTGases to dark-induced senescenceassociated responses, including the stress response, inhibition of photosynthesis, and cell death manifested by the chloroplast-to-gerontoplast conversion and degradation. Together, the presented results deepen our knowledge of the mechanisms of the events happening in dark-induced senescence of barley leaves.

Acknowledgments The authors thank Dr. Zbigniew Michalski and Dr. Robert Luciński for help in the preparation of the figures, Szymon Kubala for the statistic analysis of Figs. 2 and 3, and the European 
Center of Bioinformatics and Genomics, Poznań, Poland, where part of the experimental work was conducted. This work was supported by the National Science Center (research Grant No. N N303 418236 to E. S. N.) and by Bologna University [Fundamental Oriented Research 2011 (Grant No. RFO11DELDU to S. D. D.)].

Conflict of interest The authors declare that they have no conflict of interest.

Open Access This article is distributed under the terms of the Creative Commons Attribution License which permits any use, distribution, and reproduction in any medium, provided the original author(s) and the source are credited.

\section{References}

Altman A, Bachrach U (1981) Involvement of polyamines in plant growth and senescence. In: Caldarera CM, Zappia V, Bachrach U (eds) Advances in polyamine research, vol 3. Raven Press, New York, pp 365-375

Altschul SF, Madden TL, Schäffer AA, Zhang J, Zhang Z, Miller W, Lipman DJ (1997) Gapped BLAST and PSI-BLAST: a new generation of protein database search programs. Nucleic Acids Res 25:3389-3402

Altschul SF, Wootton JC, Gertz EM, Agarwala R, Morgulis A, Schäffer AA, Yu YK (2005) Protein database searches using compositionally adjusted substitution matrices. FEBS J 272:5101-5109

Ballestar E, Abad C, Franco L (1996) Core histones are glutaminyl substrates for tissue transglutaminase. J Biol Chem 271:18817-18824

Beninati S, Iorio RA, Tasco G, Serafini-Fracassini D, Casadio R, Del Duca S (2013) Expression of different forms of transglutaminases by immature cells of Helianthus tuberosus sprout apices. Amino Acids 44:271-283

Buchannan-Wollaston V, Ainsworth C (1997) Leaf senescence in Brassica napus: cloning of senescence related genes by subtractive hybridisation. Plant Mol Biol 33:821-834

Buchannan-Wollaston V, Earl S, Harrison E, Mathas E, Navabpour S, Page T, Pink D (2003) The molecular analysis of leaf senescencea genomics approach. Plant Biotechnol J 1:3-22

Campos A, Carvajal-Vallejos PK, Villalobos E, Franco CF, Almeida AM, Coelho AV, Torne JM, Santos M (2010) Characterisation of Zea mays L. plastidial transglutaminase: interactions with thylakoid membrane proteins. Plant Biol 12:708-716

Campos N, Villalobos E, Fontanet P, Torné JM, Santos M (2012) A peptide of 17 amino acids from the $\mathrm{N}$-terminal region of maize plastidial transglutaminase is essential for chloroplast targeting. Amer J Mol Biol 2:245-257

Campos N, Castañón S, Urreta I, Santos M, Torné JM (2013) Rice transglutaminase gene: identification, protein expression, functionality, light dependence and specific cell location. Plant Sci 205-206:97-110

Cejudo FJ, Ferrández J, Cano B, Puerto-Galán L, Guinea M (2012) The function of the NADPH thioredoxin reductase C-2-Cys peroxiredoxin system in plastid redox regulation and signalling. FEBS Lett 586:2974-2980

Corpet F (1988) Multiple sequence alignment with hierarchical clustering. Nucleic Acids Res 16:10881-10890

Del Duca S, Tidu V, Bassi R, Serafini-Fracassini D, Esposito C (1994) Identification of transglutaminase activity and its substrates in isolated chloroplast of Helianthus tuberosus. Planta 193:283-289
Del Duca S, Betti L, Trebbi G, Serafini-Fracassini D, Torrigiani P (2007) Transglutaminase activity changes during the hypersensitive reaction (HR), a typical defence response of tobacco NN plants to TMV. Physiol Plant 131:241-250

Della Mea M, Caparrós-Ruiz D, Claparols I, Serafini-Fracassini D, Rigau J (2004a) AtPng1p. The first plant transglutaminase. Plant Physiol 135:2046-2054

Della Mea M, Di Sandro A, Dondini L, Del Duca S, Vantini F, Bergamini C, Bassi R, Serafini-Fracassini D (2004b) A Zea mays $39-\mathrm{kDa}$ thylakoid transglutaminase catalyses the modification by polyamines of light-harvesting complex II in a light-dependent way. Planta 219:754-764

Della Mea M, De Filippis F, Genovesi V, Serafini-Fracassini D, Del Duca S (2007) The acropetal wave of developmental cell death (DCD) of tobacco corolla is preceded by activation of transglutaminase in different cell compartments. Plant Physiol 144:1211-1222

Dondini L, Bonazzi S, Del Duca S, Bregoli AM, Serafini-Fracassini D (2001) Acclimation of chloroplast transglutaminase to high $\mathrm{NaCl}$ concentration in a polyamine-deficient variant strain of Dunaliella salina and in its wild type. J Plant Physiol 158:185-197

Dondini L, Del Duca S, Dall'Agata L, Bassi R, Gastaldelli M, Della Mea M, Di Sandro A, Claparols I, Serafini-Fracassini D (2003) Suborganellar localisation and effect of light on Helianthus tuberosus chloroplast transglutaminase and their substrates. Planta 217:84-95

Druka A, Muehlbauer G, Druka I, Caldo R, Baumann U, Rostoks N, Schreiber A, Wise R, Close T, Kleinhofs A, Graner A, Schulman A, Langridge P, Sato K, Hayes P, McNicol J, Marshall D, Waugh $R$ (2006) An atlas of gene expression from seed to seed through barley development. Funct Integr Genomics 6:202-211

Fesus L, Thomazy V, Autuori F, Ceru MP, Tarcsa E, Piacentini M (1989) Apoptotic hepatocytes become insoluble in detergents and chaotropic agents as a result of transglutaminase action. FEBS Lett 245:150-154

Fraij BM (2014) The $55 \mathrm{kDa}$ tissue transglutaminase cross-linking active isoform TG induces cell death. Mol Carcinog. doi:10.1002/ mc.22134 [Epub ahead of print]

Gallup JM, Ackermann MR (2008) The 'PREXCEL-Q Method' for qPCR. Int J Biomed Sci 4:273-293

Griffin M, Verderio E (2000) Tissue transglutaminase in cell death In: Bryant JA, Hughes SG, Garland JM (eds) Programmed cell death in animals and plants. BIOS Scientic Publishers, Oxford, pp 223-240

Hruz T, Laule O, Szabo G, Wessendorp F, Bleuler S, Oertle L, Widmayer P, Gruissem W, Zimmermann P (2008) Genevestigator v3: a reference expression database for the meta-analysis of transcriptomes. Adv Bioinformatics 2008:420747

Huang X, Madan A (1999) CAP3: a DNA sequence assembly program. Genome Res 9:868-877

Ioannidis NE, Ortigosa SM, Veramendi J, Pintó-Marijuan M, Fleck I, Carvajal P, Kotzabasis K, Santos M, Torné JM (2009) Remodelling of tobacco thylakoids by over-expression of maize plastidial transglutaminase. Biochim Biophys Acta 1787:1215-1222

Ioannidis NE, Lopera O, Santos M, Torné JM, Kotzabasis K (2012) Role of plastid transglutaminase in LHCII polyamination and thylakoid electron and proton flow. PLoS One 7:e41979

Iorio RA, Di Sandro A, Scarpellini A, Del Duca S, Serafini-Fracassini D, Verderio E (2008) Visualisation of transglutaminase-mediated cross-linking activity in germinating pollen by laser confocal microscopy. Plant Biosyst 142:360-365

Jackowski G (1996) The subcomplex organization of the major chlorophyll $a / b$-protein complex of photosystem II (LHCII) in barley thylakoid membrane. Z Naturforsch 51:454-463

Kikuchi H, Kuribayashi F, Imajoh-Ohmi S (2014) Down-regulation of Fas-mediated apoptosis by plasma transglutaminase factor XIII 
that catalyzes fetal-specific cross-link of the Fas molecule. Biochem Biophys Res Commun 443:13-17

Kobayashi T, Takahara M, Miyagishima S, Kuroiwa H, Sasaki N, Ohta N, Matsuzaki, Kuroiwa T (2002) Detection and localization of a chloroplast-encoded HU-like protein that organizes chloroplast nucleoids. Plant Cell 14(7):1579-1589

Kulik A, Anielska-Mazur A, Bucholc M, Koen E, Szymańska K, Żmieńko A, Krzywińska E, Wawer I, McLoughlin F, Ruszkowski D, Figlerowicz M, Testerink Ch, Skłodowska A, Wendehenne D, Dobrowolska G (2012) SNF1-related protein kinases type 2 are involved in plant responses to cadmium stress. Plant Physiol 160:868-883

Larkin MA, Blackshields G, Brown NP, Chenna R, McGettigan PA, McWilliam H, Valentin F, Wallace IM, Wilm A, Lopez R, Thompson JD, Gibson TJ, Higgins DG (2007) Clustal W and clustal X version 2.0. Bioinformatics 23:2947-2948

Legocka J, Szweykowska A (1981) The role of cytokinins in the development and metabolism of barley (Hordeum) leaves 3: the effect on the ribonucleic acid (RNA) metabolism in various cell compartments during senescence. Zeitschrift fuer Pflanzenphysiologie 102:363-374

Legocka J, Zajchert I (1999) Role of spermidine in the stabilization of the apoprotein of the light-harvesting chlorophyll $a / b$-protein complex of photosystem II during leaf senescence process. Acta Physiol Plant 21:127-132

Lilley G, Skill J, Griffin M, Bonner P (1998) Detection of $\mathrm{Ca}^{2+}$ dependent transglutaminase activity in root and leaf tissue of monocotyledoneus and dicotyledoneous plants. Plant Physiol 117:1115-1123

Lorand L, Graham RM (2003) Transglutaminases: crosslinking enzymes with pleiotropic functions. Nat Rev Mol Cell Biol 4:140-156

Marcé M, Brown DS, Capell T, Figueras X, Tiburcio AF (1995) Rapid high performance liquid chromatographic method for the quantitation of polyamines as their dansyl derivatives: application to plant and animal tissues. J Chromatogr B Biomed Appl 666:329-335

Marchler-Bauer A, Lu S, Anderson JB, Chitsaz F, Derbyshire MK, DeWeese-Scott C, Fong JH, Geer LY, Geer RC, Gonzales NR, Gwadz M, Hurwitz DI, Jackson JD, Ke Z, Lanczycki CJ, Lu F, Marchler GH, Mullokandov M, Omelchenko MV, Robertson CL, Song JS, Thanki N, Yamashita RA, Zhang D, Zhang N, Zheng C, Bryant SH (2011) CDD: a conserved domain database for the functional annotation of proteins. Nucleic Acids Res 39 (Database issue):D225-D229

Margosiak SA, Dharma A, Bruce-Carver MR, Gonzales AP, Louie D, Kuehn GD (1990) Identification of the large subunit of ribulose 1,5-bisphosphate carboxylase/oxygenase as a substrate for transglutaminase in Medicago sativa L. (alfalfa). Plant Physiol 92:88-96

Matsumoto T, Tanaka T, Sakai H, Amano N, Kanamori H, Kurita K, Kikuta A, Kamiya K, Yamamoto M, Ikawa H, Fujii N, Hori $\mathrm{K}$, Itoh T, Sato K (2011) Comprehensive sequence analysis of 24,783 barley full-length cDNAs derived from 12 clone libraries. Plant Physiol 156:20-28

Mattoo AK, Minocha SC, Minocha R, Handa AK (2010) Polyamines and cellular metabolism in plants: transgenic approaches reveal different responses to diamine putrescine versus higher polyamines spermidine and spermine. Amino Acids 38:405-413

Melonek J, Matros A, Trösch M, Mock HP, Krupinska K (2012) The core of chloroplast nucleoids contains architectural SWIB domain proteins. Plant Cell 24:3060-3073

Moschou PN, Sanmartin M, Andriopoulou AH, Rojo E, SanchezSerrano JJ, Roubelakis-Angelakis KA (2008) Bridging the gap between plant and mammalian polyamine catabolism: a novel peroxisomal polyamine oxidase responsible for a full back-conversion pathway in Arabidopsis. Plant Physiol 147:1845-1857

Noushina I, Nazar R, Khan MIR, Masood A, Khan NA (2011) Role of gibberellins in regulation of source-sink relations under optimal and limiting environmental conditions. Curr Sci 100:998-1007

Novakoudis E, Vrentzou K, Kotzabasis K (2007) A polyamine-and LHCII protease activity-based mechanism regulates the plasticity and adaptation status of the photosynthetic apparatus. Biochim Biophys Acta 1767:261-271

Ortigosa SM, Díaz-Vivancos P, Clemente-Moreno MJ, Pintó-Marijuan M, Fleck I, Veramendi J, Santos M, Hernandez JA, Torné JM (2010) Oxidative stress induced in tobacco leaves by chloroplast over-expression of maize plastidial transglutaminase. Planta 232:593-605

Pfaffl MW, Horgan GW, Dempfle L (2002) Relative expression software tool (REST) for group-wise comparison and statistical analysis of relative expression results in real-time PCR. Nucleic Acids Res 30:e36

Piacentini M, Melino G (1994) Role of tissue transglutaminase in neuroblastoma cells undergoing apoptosis. Prog Clin Biol Res 385:123-129

Sarwat M, Naqvi AR, Ahmad P, Ashraf M, Akram NA (2013) Phytohormones and microRNAs as sensors and regulators of leaf senescence: assigning macro roles to small molecules. Biotechnol Adv 31:1153-1171

Serafini-Fracassini D, Del Duca S (2008) Transglutaminases: widespread cross-linking enzymes in plants. Ann Bot 102:145-152

Serafini-Fracassini D, Del Duca S, Monti F, Poli F, Sacchetti G, Bregoli AM, Biondi S, Della Mea M (2002) Transglutaminase activity during senescence and programmed cell death in the corolla of tobacco (Nicotiana tabacum) flowers. Cell Death Differ 9:309-321

Serafini-Fracassini D, Della Mea M, Tasco G, Casadio R, Del Duca S (2009) Plant and animal transglutaminases: do similar functions imply similar structures? Amino Acids 36:643-657

Serafini-Fracassini D, Di Sandro A, Del Duca S (2010) Spermine delays leaf senescence in Lactuca sativa and prevents the decay of chloroplast photosystems. Plant Physiol Biochem 48:602-611

Sobieszczuk-Nowicka E, Legocka J (2014) Plastid-associated polyamines: their role in differentiation, structure, functioning, stress response and senescence. Plant Biol 16:297-305

Sobieszczuk-Nowicka E, Di Sandro A, Del Duca S, Serafini-Fracassini D, Legocka J (2007) Plastid-membrane-associated polyamines and thylakoid transglutaminases during etioplast-tochloroplast transformation stimulated by kinetin. Physiol Plant 130:590-600

Sobieszczuk-Nowicka E, Krzesłowska M, Legocka J (2008) Transglutaminases and their substrates in kinetin stimulated etioplastto-chloroplast transformation in cucumber cotyledons. Protoplasma 233:187-194

Sobieszczuk-Nowicka E, Wieczorek P, Legocka J (2009) Kinetin affects the level of chloroplast polyamines and transglutaminase activity during senescence of barley leaves. Acta Biochim Pol $56: 255-259$

Takahashi T, Kakehi J (2010) Polyamines: ubiquitous polycations with unique roles in growth and stress responses. Ann Bot 105:1-6

Van der Graaff E, Schwacke R, Desimone M, Flugge UI, Kunze R (2006) Transcription analysis of Arabidopsis membrane transporters and hormone pathways during developmental and induced leaf senescence. Plant Physiol 141:776-792

Van Doorn W, Yoshimoto K (2010) Role of chloroplasts and other plastids in ageing and death of plants and animals: a tale of Vishnu and Shiva. Ageing Res Rev 9:117-130

Villalobos E, Santos M, Talavera D, Rodríguez-Falcón M, Torné JM (2004) Molecular cloning and characterization of a maize transglutaminase complementary DNA. Gene 336:93-104 
Walden R, Cordeiro A, Tiburcio AF (1997) Polyamines: small molecules triggering pathways in plant growth and development. Plant Physiol 113:1009-1013

Wang W, Vinocur B, Shoseyov O, Altman A (2004) Role of plant heat-shock proteins and molecular chaperones in the abiotic stress response. Trends Plant Sci 9:244-252
Żelisko A, Jackowski G (2004) Senescence-dependent degradation of Lhcb3 is mediated by a thylakoid membrane-bound protease. $\mathrm{J}$ Plant Physiol 161:1157-1170 